\title{
PELANGGARAN PRINSIP KESANTUNAN BERBAHASA DALAM SINETRON "SIAPA TAKUT JATUH CINTA"
}

\author{
Irni Cahyani and Sri Munalisa
}

STKIP PGRI Banjarmasin

email: irnicahyani08091987@gmail.com, mujilah.rahmah@gmail.com

\begin{abstract}
ABSTRAK
Penelitian ini membahas tentang pelanggaran prinsip kesantunan berbahasa dalam sinetron "Siapa Takut Jatuh Cinta" di SCTV. Masalah yang diteliti adalah bagaimana wujud pelanggaran prinsip kesantunan berbahasa dan faktor penyebab ketidaksantunan berbahasa dalam sinetron "Siapa Takut Jatuh Cinta." Tujuan penelitian ini yaitu (1) mendeskripsikan wujud pelanggaran prinsip kesantunan berbahasa dan (2) memaparkan faktor penyebab ketidaksantunan berbahasa dalam sinetron "Siapa Takut Jatuh Cinta. "Pendekatan yang digunakan dalam penelitian adalah pendekatan pragmatik. Jenis penelitian ini termasuk jenis penelitian kualitatif deskriptif. Sumber data yang diambil 4 episode dalam sebuah sinetron yang berjudul "Siapa Takut Jatuh Cinta." Prosedur pengumpulan data dalam penelitian ini menggunakan teknik observasi teks. Teknik analisis data dalam penelitian ini adalah pengumpulan data, pengelompokkan data, dan penginterpretasian. Intrumen penelitian dikelompokkan sesuai dengan pelanggaran kesantunan berbahasa, dan rencana pengujian keabsahan data dengan pengumpulan data, reduksi data, dan pengelompokkan data. Berdasarkan penelitian diperoleh simpulan sebagai berikut: (1) pelanggaran prinsip kesantunan berbahasa menurut Leech yang berkaitan dengan hubungan antara peserta tuturan dan lawan tutur, yaitu: (a) maksim kebijaksanaan, (b) maksim penerimaan, (c) maksim kemurahan, (d) maksim kerendahan hati, (e) maksim kecocokan dan (f) maksim kesimpatian. (2) faktor penyebab pelanggaran prinsip kesantunan, yaitu: (a) kritik secara langsung dengan kata-kata kasar, (b) dorongan rasa emosi penutur, (c) protektif terhadap pendapat (d) sengaja menuduh lawan tutur, (e) sengaja memojokkan lawan tutur.
\end{abstract}

Kata Kunci: pelanggaran, pragmatik, sinetron

\section{PENDAHULUAN}

Di zaman modern saat ini banyak sinetron yang tidak menggunakan bahasa yang santun. Padahal sinetron yang ditayangkan banyak ditonton oleh masyarakat. Apalagi sinetron tersebut diperankan oleh artis yang banyak disukai oleh masyarakat, maka apapun tingkah laku ataupun tuturan yang dilakukan oleh artis akan ditiru, sehingga sinetron yang tidak menggunakan bahasa yang santun akan berdampak sangat tidak baik bagi masyarakat yang menontonnya.

Manusia adalah makhluk sosial memerlukan alat untuk berkomunikasi dengan sesamanya. Bahasa adalah alat untuk berkomunikasi antar manusia. Dalam lingkungan sosial budaya, komunikasi antar manusia dibatasi oleh nilai-nilai yang disepakati bersama. Dalam komunikasi, bahasa tidak saja menjadi alat komunikasi, tetapi juga merupakan ciri dari derajat pengguna bahasa 
di antara sesamanya. Bahasa yang memiliki makna dan nilai bagi para penuturnya disebut bahasa yang santun (Sauri, 2005:55).

Bahasa yang digunakan dalam berkomunikasi bermasyarakat haruslah yang santun. Dengan menggunakan bahasa yang santun, maka sesama manusia bisa saling berkomunikasi dengan baik, sehingga komunikasi antar manusia dengan manusia lainnya dapat berjalan dengan lancar dan tidak ada pihak yang merasa tersinggung dengan yang tuturan yang disampaikan.

Dengan menggunakan bahasa, maka akan lebih mudah dalam menyampaikan informasi ataupun pendapat yang ingin disampaikan kepada orang lain, karena tanpa bahasa manusia akan kesulitan dalam berkomunikasi dan berinteraksi dengan masyarakat. Bahasa yang kita gunakan untuk bertutur kepada orang lain haruslah bahasa yang baik, karena bahasa adalah sebagai alat untuk berkomunikasi dan berinteraksi dengan orang lain.

Komunikasi antar manusia terbanyak dilakukan dengan lisan atau melalui berbicara. Oleh karena itu, secara mendasar bahwa kemampuan berbicara menduduki peranan penting dalam komunikasi antara sesama. Di mana-mana kita menyaksikan orang berbicara satu sama lain. Pembicaran terjadi di pasar, di kantor, di rumah, di sekolah, di bandara, di forum-forum resmi, di pergaulan sehari-hari di kampung atau di masyarakat, dan tempat juga kesempatan lainnya yang sangat beragam. Antar sesama, orang berbicara dengan bahasa tertentu. Mereka saling memahami. Sudah menjadi kesempatan alami bahwa jika orang ingin berkomunikasi satu sama lain, maka harus menggunakan bahasa yang sama, ada yang harus menyesuaikan diri, jika sebelumnya yang terlibat bicara berlatar belakang bahasa yang berbeda (Musaba, 2012:13).

Penggunaan bahasa yang tidak sesuai dengan faktor-faktor penentu berkomunikasi atau penggunaan bahasa yang tidak sesuai dengan norma kemasyarakatan bukanlah berbahasa Indonesia dengan baik. Berbahasa Indonesia yang menyimpang dari kaidah atau aturan tata bahasa Indonesia, jelas pula bukan berbahasa dengan benar. Kesimpulannya, kesalahan berbahasa adalah penggunaan bahasa baik, secara lisan maupun tertulis yang menyimpang dari faktor-faktor penentu berkomunikasi atau menyimpang dari norma kemasyarakatan dan menyimpang dari kaidah tata bahasa Indonesia (Setyawati, 2010:15).

Menggunakan bahasa yang tidak santun dalam bertutur akan membuat lawan tutur tersinggung dengan apa yang diucapkan, maka seharusnya menggunakan bahasa yang santun dalam bertutur, baik dalam acara formal maupun informal, sehingga tidak akan membuat lawan tutur kita tersinggung dengan tuturan yang kita sampaikan. Apalagi dalam sebuah sinetron yang banyak ditonton orang, seharusnya menggunakan bahasa yang santun dalam bertutur. 
Kesantunan berbahasa seseorang akan dapat tercapai dengan baik, apabila dia telah mampu mengendalikan emosinya. Orang seperti ini, pada akhirnya, akan memiliki kecerdasan emosional (emotional intelligence) yang tinggi. Sebagaimana kita ketahui, kecerdasan adalah kemampuan manusia menjaga keseimbangan kecerdasan intelektual (intellectual intelligence) dan kecerdasan emosional (emotional intelligence) dalam mengatasi segala kehidupan, sehingga mencapai hasil yang baik dan bermutu (Sibarani, 2004: 201).

Kesantunan dalam berbahasa sangat penting, apalagi dalam sebuah sinetron yang tampil di layar televisi yang banyak ditonton oleh masyarakat, karena menjadi tontonan seharusnya sinetron harus mencontohkan hal-hal yang baik, agar berdampak positif bagi yang menonton.

Sinetron "Siapa Takut Jatuh Cinta” adalah salah satu sinetron yang saat ini banyak digemari anak muda yang tayang setiap hari pukul 18:00 WIB di SCTV. Dalam sinetron ini mengisahkan tentang percintaan anak muda yang saling jatuh cinta satu sama lain. Dibintangi oleh artis yang sedang naik daun yaitu artis tampan Verrell Bramasta Fadilla berperan sebagai Vino dengan artis cantik Natasya Wilona berperan sebagai Laras. Di sinetron tersebut mereka dipasangkan sebagai sepasang kekasih yang romantis.

Peneliti memilih untuk meneliti penelitian ini, karena banyak sinetron yang melanggar kesantunan berbahasa yang seharusnya tidak bisa dijadikan tontonan untuk masyarakat. Apalagi yang menonton anak muda yang sangat mudah dalam meniru apa yang mereka lihat ataupun yang mereka tonton, sehingga berdampak tidak baik bagi anak muda yang menonton sinetron tersebut.

Tuturan-tuturan yang digunakan dalam sinetron "Siapa Takut Jatuh Cinta" menarik untuk diteliti. Meskipun dalam sinetron "Siapa Takut Jatuh Cinta" terdapat tuturan yang mematuhi dan melanggar prinsip kesantunan, yang akan diteliti yaitu tuturan yang menunjukkan ketidaksantunan tuturan kepada orang lain.

Dalam sinetron tersebut seringkali para pemainnya melanggar kesantunan berbahasa, sehingga menimbulkan ketersinggungan terhadap lawan pemainnya. Seharusnya film yang menjadi tontonan masyarakat harus menggunakan bahasa yang santun dalam berkomunikasi antar pemainnya, agar tidak tersinggung dengan perkataan yang diucapkan, karena menjadi tontonan masyarakat sinetron yang menampilkan bahasa yang tidak santun akan ditiru oleh masyarakat yang menontonnya.

Penelitian tentang pelanggaran prinsip kesantunan yang sejenis atau relevan yaitu penelitian berupa jurnal Nisa (2016) "Pelanggaran Prinsip Kesantunan dalam Wacana Tutur Basuki Tjahaja Purnama (Ahok)." Hasil penelitian ini adalah sebagai berikut. Wujud pelanggaran prinsip 
pelanggaran Leech yang meliputi: (1) pelanggaran maksim kebijaksanaan, pelanggaran maksim penerimaan, pelanggaran maksim kemurahan, pelanggaran maksim kerendahan hati, pelanggaran kesetujuan, dan pelanggaran maksim kesimpatian. (2) Fungsi tuturan dari pelanggaran prinsip kesantunan pada wacana tutur Ahok, yaitu: (a) fungsi pelanggaran prinsip kesantunan dalam tindak tutur direktif, meliputi: perintah, permintaan, larangan, pertanyaan, dan persyaratan. (b) fungsi pelanggaran prinsip kesantunan dalam tindak tutur ekspresif meliputi: mengejek, marah, frustasi, dan mengecam, dan (c) fungsi pelanggaran prinsip kesantunan dalam tindak tutur asertif, meliputi: memberi alasan, memberitahu, menegaskan, menyatakan, menceritakan dan bersikeras.

Perbedaan penelitian ini dengan penelitian sebelumnya terdapat pada subjek yang diteliti. Subjek pada penelitian ini memfokuskan pada tuturan pemain sinetron "Siapa Takut Jatuh Cinta." Hasil penelitian membahas mengenai bentuk pelanggaran dan faktor penyebab pelanggaran prinsip kesantunan berbahasa pada sinetron "Siapa Takut jatuh Cinta." Berdasarkan latar belakang di atas, peneliti tertarik untuk melakukan penelitian yang berjudul "Pelanggaran Prinsip Kesantunan Berbahasa dalam sinetron "Siapa Takut Jatuh Cinta."

\section{METODE}

Pendekatan yang digunakan dalam penelitian ini adalah pendekatan pragmatik. Jenis penelitian pragmatik dipilih, karena penelitian ini termasuk dalam kajian pragmatik. Pendekatan ini dipilih, karena adanya pertimbangan peneliti dalam penelitian ini untuk menguraikan kata-kata para pemain sinetron "Siapa Takut Jatuh Cinta" yang melanggar prinsip kesantunan berbahasa (Mahdian, 2015: 31).

Adapun jenis penelitian ini termasuk jenis penelitian kualitatif yang bersifat deskriptif. Pendekatan kualitatif menurut Moleong dalam Mahdian (2015: 31), dalam kajiannya menyatakan bahwa metode deskriptif menjelaskan data atau objek secara natural, objektif, dan faktual (apa adanya). Metode deskriptif dipilih oleh peneliti, karena metode ini dapat memberikan gambaran yang secermat mungkin tentang individu, keadaan bahasa, gejala atau kelompok tertentu.

Prosedur pengumpulan data dengan menggunakan teknik observasi teks. Teknik tersebut yakni dengan cara mencari dan mengumpulkan beberapa data dengan melalui cara membaca, serta mengamati sumber data dari penelitian ini, yaitu sumber datanya adalah sebuah skenario sinetron "Siapa Takut Jatuh Cinta" yang ditayangkan di SCTV. 


\section{HASIL DAN PEMBAHASAN}

Hasil penelitian yang akan disajikan adalah berupa pelanggaran kesantunan berbahasa dalam “Sinetron Siapa Takut Jatuh Cinta.” Jenis yang diteliti yaitu berupa pelanggaran prinsip kesantunan berbahasa dan faktor penyebab ketidaksantunan berbahasa dalam sinetron "Siapa Takut Jatuh Cinta." Hasil penelitian ini diidentifikasi berdasarkan pelanggaran prinsip kesantunan berbahasa dan faktor penyebab ketidaksantunan berbahasa. Tahap pertama yaitu mengunduh naskah skenario Sinetron Siapa Takut Jatuh Cinta. Kemudian tahap kedua, penganalisisan dan pembenahannya. Pada tahap pertama, peneliti menyimak percakapan tuturan-tuturan para pemain "Sinetron Siapa Takut Jatuh Cinta," kemudian mencatat dialog ke dalam sebuah tulisan. Selanjutnya, pada tahap kedua data tersebut diklasifikasi dan dianalisis berdasarkan pelanggaran prinsip kesantunan berbahasa dan faktor penyebab ketidaksantunan.

Berdasarkan teori, ada enam prinsip kesantunan dalam berbahasa pada percakapan sinetron "Siapa Takut Jatuh Cinta" yaitu maksim kebijaksanaan, maksim penerimaan, maksim kemurahan, maksim kerendahan hati, maksim kecocokan, dan maksim kesimpatian, dan bentuk pelanggaran kesantunan terhadap penyebab ketidaksantunan pada percakapan sinetron "Siapa Takut Jatuh Cinta" yaitu kritik secara langsung dengan kata-kata kasar, dorongan rasa emosi penutur, protektif terhadap pendapat, dan sengaja menuduh lawan tutur. Setelah dilakukan penelitian terhadap pelanggaran kesantunan berbahasa pada sinetron "Siapa Takut Jatuh Cinta” yang ditemukan.

Berdasarkan hasil penelitian yang diunduh dan kemudian ditranskripsikan ke dalam bentuk tulisan. Dari hasil 4 episode sinetron yang diunduh diperoleh data tentang pelanggaran prinsip kesantunan berbahasa dalam Sinetron "Siapa Takut Jatuh Cinta." Wujud pelanggaran prinsip kesantunan berbahasa yaitu pelanggaran maksim kebijaksanaan, maksim penerimaan, maksim kemurahan, maksim kerendahan hati, maksim kecocokan, dan maksim kesimpatian.

Maksim kebijaksanaan menggariskan bahwa setiap peserta pertuturan harus meminimalkan kerugian orang lain atau memaksimalkan keuntungan bagi orang lain.

\section{Data Percakapan 1}

Dialog: Laras memaki Vino tentang Vino yang menabrak Laras dan menyebabkan Laras terjatuh dari motornya.

Laras: "Mobil lu.. oh.. pantesan bawanya ugal-ugalan, ternyata lu yang bawa"

Vino: "Iya emangnya kenapa?"

(Sumber: Sinetron “Siapa Takut Jatuh Cinta," episode 1, 13 November 2017) 
Tuturan Laras tersebut merupakan bentuk pelanggaran prinsip kesantunan dalam maksim kebijaksanaan. Pelanggaran maksim tersebut terdapat pada kutipan di atas yang dituturkan oleh Laras, yaitu “Mobil lu..oh..pantesan yang bawanya ugal-ugalan, ternyata elu yang bawa.” Tuturan yang diucapkan oleh Laras tersebut tidak memberikan keuntungan bagi Vino. Tuturan Laras justru merugikan Vino yang dinilainya ugal-ugalan membawa mobil. Hal ini tidak sesuai dengan penerapan maksim kebijaksanaan, yaitu memberikan keuntungan yang maksimal kepada orang lain dan meminimalkan kerugian bagi orang lain.

\section{Data Percakapan 2}

Dialog: Laras memaki Vino, karena Vino hampir menabrak Laras untuk yang kedua kalinya, sehingga membahayakan nyawanya.

Laras: "Asal lu tau ya gara-gara lu yang nggak becus bawa mobil, udah dua kali nyusahin hidup gue, pertama gue hampir aja kehilangan pekerjaan, gue hampir dipecat dan sekarang lu sudah membahayakan nyawa gue."

Vino: "Gue sudah nawarin ganti rugi ya hari itu sama lu, lu aja yang sok-sok jual mahal, ya udah sekarang gue nggak mau dibilang gue nggak bertanggungjawab, lu plin plan gue nggak."

(Sumber: Sinetron “Siapa Takut Jatuh Cinta,” episode 1, 13 November 2017)

Tuturan Laras pada kutipan di atas melanggar prinsip kesantunan, yaitu maksim kebijaksanaan. Maksim kebijaksanaan penutur harus meminimalkan kerugian orang lain dan memaksimalkan keuntungan orang lain. Dari tuturan Laras di atas terlihat bahwa Laras tidak memaksimalkan keuntungan orang lain dan meminimalkan kerugian orang lain terhadap Vino. Hal ini terlihat pada tuturan "asal lu tau ya gara-gara lu yang nggak becus bawa mobil, udah dua kali nyusahin hidup gue, pertama gue hampir aja kehilangan pekerjaan, gue hampir dipecat dan sekarang lu sudah membahayakan nyawa gue.” yang dituturkan oleh Laras. Tuturan Laras tersebut menyebutkan bahwa Vino yang tidak becus membawa mobil yang mengakibatkan ia terjatuh dan hampir kehilangan pekerjaannya, serta membahayakan nyawanya. Tuturan Laras tersebut tidak sesuai dengan penerapan maksim kebijaksanaan yaitu memberikan keuntungan semaksimal mungkin kepada orang lain dan meminimalkan kerugian bagi orang lain.

\section{Data percakapan 3}

Dialog: Vino memaki Laras, karena Laras menolak penawaran ganti rugi terhadap kesalahan yang Vino lakukan. 
Laras: "Asal lu tau ya gara-gara lu yang nggak becus bawa mobil, udah dua kali nyusahin hidup gue, pertama gue hampir aja kehilangan pekerjaan, gue hampir dipecat dan sekarang lu sudah membahayakan nyawa gue."

Vino: "Gue sudah nawarin ganti rugi ya hari itu sama lu, lu aja yang sok-sok jual mahal, ya udah sekarang gue nggak mau dibilang gue nggak bertanggungjawab, lu plin plan gue nggak."

(Sumber: Sinetron “Siapa Takut Jatuh Cinta," episode 1, 13 November 2017)

Dalam tuturan Vino tersebut terdapat pelanggaran maksim kebijaksanaan. Hal ini terlihat dari tuturan Vino kepada Laras. Tuturan Vino "gue sudah nawarin ganti rugi ya hari itu sama lu, lu aja yang sok-sok jual mahal, ya udah sekarang gue nggak mau dibilang gue nggak bertanggungjawab, lu plin plan gue nggak. Gue sudah nawarin ganti rugi ya hari itu sama lu, lu aja yang sok-sok jual mahal, ya udah sekarang gue nggak mau dibilang gue nggak bertanggungjawab, lu plin plan gue nggak.” Merupakan pelanggaran maksim kebijaksanaan. Vino yang mau dikatakan tidak bertanggungjawab oleh Laras, sehingga ia bertutur bahwa Laras "sok-sok jual mahal," karena tidak mau menerima tawaran Vino untuk mengganti rugi dengan uang, karena Vino merasa dengan uang ia tidak akan disalahkan. Merupakan pelanggaran maksim kebijaksanaan, karena Vino tidak memaksimalkan keuntungan bagi Laras dan justru memaksimalkan kerugian bagi Laras.

\section{Data Percakapan 4}

Dialog: Vino memaki Laras, karena Laras menolak penawaran ganti rugi terhadap kesalahan yang Vino lakukan.

Vino: "Udahlah nggak usah nggak perlu. Sebutin aja butuh duit berapa?

Kurang, gue kasih lagi, cukup."

Laras: "Ehh gue bilang nggak perlu, gue nggak perlu duit lu, gue cuma butuh lu minta maaf sama gue."

(Sumber: Sinetron “Siapa Takut Jatuh Cinta," episode 1, 13 November 2017)

Tuturan Vino pada kutipan di atas melanggar prinsip kesantunan, yaitu maksim kebijaksanaan. Pelanggaran maksim tersebut terdapat pada kutipan yang dituturkan oleh Vino, yaitu "udah nggak usah, nggak perlu." Tuturan yang disampaikan oleh Vino tersebut tidak memberikan keuntungan bagi Laras. Tuturan Vino justru merugikan Laras yang dinilainya hanya dengan uang, ia bisa minta maaf kepada orang lain, karena ia merasa dengan uang semuanya bisa selesai. 


\section{Data Percakapan 5}

Dialog: Bianca memaki Laras, karena Laras adalah orang miskin dan susah, sehingga menurut Bianca Laras tidak pantes kuliah di tempatnya.

Bianca: "Susah.. ya sih lu keliatan banget orang susah, oh ya gue denger-denger tadi lu dipecat dari kerjaan lu, wow..kuliah sambil kerja, miskin dong lu."

Laras: "Trus, lu mau bilang gue nggak pantes kuliah disini." (Sumber: Sinetron “Siapa Takut Jatuh Cinta," episode 1, 13 November 2017)

Dalam tuturan Bianca pada kutipan di atas melanggar prinsip kesantunan, yaitu maksim kebijaksanaan. Maksim ini berhubungan dengan memaksimalkan keuntungan orang lain dan meminimalkan kerugian orang lain. Dari tuturan Bianca terlihat bahwa Bianca tidak memaksimalkan keuntungan bagi orang lain dan meminimalkan kerugian orang lain. Hal ini terlihat pada tuturan "lu keliatan banget orang susah,” yang dikatakan oleh Bianca. Tuturan Bianca itu menghina Laras orang susah dan miskin, sehingga ia kuliah sambil bekerja. Tuturan Bianca menggunakan sebutan "lu keliatan banget orang susah." Merupakan pelanggaran maksim kebijaksanaan, karena Bianca tidak memaksimalkan keuntungan orang lain dan kerugian orang lain.

\section{Pelanggaran Maksim Penerimaan}

Maksim penerimaan menghendaki setiap peserta pertuturan untuk memaksimalkan kerugian bagi diri sendiri dan meminimalkan keuntungan diri sendiri.

\section{Percakapan Dialog 17}

Dialog: Laras menolak penawaran Vino untuk ganti rugi memakai uang, sedangkan Laras inginnya Vino meminta maaf kepadanya.

Vino: "Udahlah nggak usah sok perlu. Sebutin aja butuh duit berapa?"

Laras: "Ehh gue gak perlu duit lu, gue cuma butuh lu minta maaf sama gue." (Sumber: Sinetron “Siapa Takut Jatuh Cinta," episode 1, 13 November 2017)

Tuturan Laras tersebut merupakan bentuk pelanggaran prinsip kesantunan dalam maksim penerimaan. Pada tuturan tersebut terdapat pelanggaran maksim penerimaan yang dituturkan oleh Laras, yaitu pada tuturan "Ehh gue nggak perlu, gue nggak perlu duit lu, gue cuma butuh lu minta maaf sama gue," tuturan Laras tersebut merupakan pelanggaran maksim penerimaan, karena dia tidak memaksimalkan kerugian bagi dirinya sendiri, yaitu Laras tidak mau uang yang diberikan oleh Vino, tetapi yang ia butuhkan hanyalah permintaan maaf dari Vino. Hal ini tidak sesuai dengan 
penerapan maksim penerimaan yang dikehendaki setiap peserta pertuturan untuk memaksimalkan kerugian bagi diri sendiri dan meminimalkan keuntungan diri sendiri.

\section{Percakapan Dialog 18}

Dialog: Vino tidak mau lagi bertemu Laras dan Laras juga tidak mau bertemu lagi sama Vino.

Vino: "Awas kalo ketemu lu lagi!"

Laras: "Gue juga nggak mau ketemu lu lagi, minggir."

(Sumber: Sinetron “Siapa Takut Jatuh Cinta,” episode 1, 13 November 2017)

Tuturan Laras pada kutipan di atas, melanggar prinsip kesantunan, yaitu maksim penerimaan. Maksim penerimaan menuntut setiap peserta pertuturan untuk memaksimalkan keuntungan orang lain dan meminimalkan keuntungan diri sendiri. Dari tuturan Laras di atas, terlihat bahwa Laras tidak memaksimalkan keuntungan orang lain dan meminimalkan keuntungan kepada Vino. Hal ini terlihat pada "gue juga nggak mau ketemu lu lagi, minggir" yang dituturkan oleh Laras. Dari tuturan Laras tersebut bahwa ia tidak mau lagi bertemu Vino. Hal ini tidak sesuai dengan penerapan maksim penerimaan yang menghendaki setiap peserta pertuturan untuk memaksimalkan kerugian bagi diri sendiri dan meminimalkan keuntungan diri sendiri.

\section{Percakapan Dialog 19}

Dialog: Bos tidak terima permintaan maaf Laras, kecuali kata Bosnya permintaan maafnya bisa menjadi uang.

Laras: "Iya maaf Bos, soalnya tadi kejadiannya pas lagi on the way ngantar box makanan."

Bos: "Maaf lu nggak guna buat gue, kecuali maaf lu berubah jadi duit, baru guna, hah ayo kita hitung kerugiannya."

(Sumber: Sinetron “Siapa Takut Jatuh Cinta,” episode 1, 13 November 2017)

Dalam tuturan bos di atas, terdapat pelanggaran maksim penerimaan. Hal ini terlihat dari tuturan Bos yang tidak memaksimalkan kerugian bagi diri sendiri dan meminimalkan keuntungan diri sendiri terhadap tuturan bos yang dituturkan oleh bos kepada Laras. Hal ini terlihat pada, “Maaf lu nggak guna buat gue, kecuali maaf lu berubah jadi duit, baru guna” hah ayo kita hitung kerugiannya." Merupakan bentuk penolakan terhadap tuturan Laras tersebut telah melanggar prinsip kesantunan dari maksim penerimaan. 


\section{Pelanggaran Maksim Kerendahan Hati}

Maksim menuntut setiap peserta pertuturan untuk memaksimalkan ketidakhormatan pada diri sendiri dan meminimalkan rasa hormat pada diri sendiri.

\section{Percakapan Dialog 37}

Dialog: Laras yang tidak mau menerima uang Vino, karena yang Laras butuhkan hanyalah permintaan maaf Vino, tetapi Vino tidak mau minta maaf, karena Vino merasa dirinya orang kaya.

Laras: "Nggak, gue sudah bilang, gue nggak mau uang lu gue cuma mau lu minta maaf sama gue."

Vino: "Lu nggak tau siapa gue?"

(Sumber: Sinetron “Siapa Takut Jatuh Cinta,” episode 1, 13 November 2017)

Dilihat dari tuturan Vino dalam sebuah dialog percakapan tersebut melanggar prinsip kesantunan. Tuturan Vino “lu nggak tau gue siapa?” telah melanggar maksim kerendahan hati. Berdasarkan tuturan Vino tersebut, terlihat bahwa Vino menyombongkan dirinya kepada Laras. Hal ini tidak sesuai dengan penerapan maksim kerendahan hati yaitu memaksimalkan ketidakhormatan pada diri sendiri dan meminimalkan rasa hormat pada diri sendiri.

\section{Percakapan Dialog 38}

Dialog: Bianca menghina Laras dengan menyebut Laras sebagai gembel.

Bianca: "Attention guys...guys... gue mau kasih tau aja, ada gembel masuk kampus kita, so jadi save aja barang-barang kalian, karena siapa tau kalo dia lagi butuh uang, barang-barang kalian deh dan gue, mau kasih tau aja nih ya jauhjauh deh sama tuh cewek."

Laras: "Tett...salah dua-duanya orang tua gue nggak jual apa dua-duanyapun..gue masuk kesini gratis..karna apa? Karna gue pinter dapat beasiswa, lu nggak sepinter gue."

(Sumber: Sinetron “Siapa Takut Jatuh Cinta," episode 1, 13 November 2017)

Tuturan Laras pada kutipan di atas melanggar prinsip kesantunan, yaitu maksim kerendahan hati. Maksim kerendahan hati memaksimalkan ketidakhormatan pada diri sendiri dan meminimalkan rasa hormat pada diri sendiri. Dari tuturan Laras terlihat bahwa Laras tidak memaksimalkan ketidakhormatan pada diri sendiri dan meminimalkan rasa hormat pada diri sendiri. Hal ini terlihat pada tuturan "karna gue pinter dapat beasiswa, lu nggak sepinter gue" yang disampaikan oleh Laras. Merupakan pelanggaran maksim kerendahan hati, karena Laras memaksimalkan rasa hormat pada dirinya, karena ia merasa pintar. 


\section{Pelanggaran Maksim Kecocokan}

Maksim kecocokan menghendaki, agar setiap penutur dan lawan tutur memaksimalkan kesetujuan di antara mereka dan meminimalkan ketidaksetujuan di antara mereka.

\section{Percakapan Dialog 40}

Dialog: Papanya Leon menegur Leon, karena ia membawa seorang perempuan ke rumah.

Leon: "Tadikan dia sudah ngenalin nama, nama dia Dara teman aku dari Amrik, dia itu."

Papa: "Kamu ngerti maksud papa, kamu suruh papa untuk balik, bukan untuk mainmain, malah sekarang kamu bawa teman perempuan, kalo ini jadi masalah, papa akan lepas tangan, mulai sekarang kamu harus bisa bertanggungjawab, hidup kamu sendiri."

(Sumber: Sinetron "Siapa Takut Jatuh Cinta," episode 1, 13 November 2017)

Dalam tuturan ayahnya Leon di atas, terdapat pelanggaran maksim kesetujuan atau kecocokan. Hal ini terlihat dari tuturan ayahnya Leon yang tidak memaksimalkan kesetujuan terhadap tuturan Leon. Tuturan ayahnya Leon "Kamu ngerti maksud papa, kamu suruh papa untuk balik, bukan untuk main-main, malah sekarang kamu bawa teman perempuan, kalo ini jadi masalah, papa akan lepas tangan, mulai sekarang kamu harus bisa bertanggungjawab, hidup kamu sendiri" merupakan bentuk penolakan atau ketidaksetujuan terhadap tuturan Leon. Dengan demikian, tuturan ayah Leon tersebut telah melanggar prinsip kesantunan dari maksim kesetujuan.

\section{Percakapan Dialog 41}

Dialog: Laras marah karena Vino sudah menabraknya walaupun ia tidak terluka.

Vino: "Lu nggak papakan, nggak luka."

Laras: "Trus kalo gue nggak papa, perbuatan lu tadi bisa dimaafin."

(Sumber: Sinetron “Siapa Takut Jatuh Cinta,” episode 1, 13 November 2017)

Tuturan Laras pada kutipan di atas, melanggar prinsip kesantunan, yaitu maksim kesetujuan atau kecocokan. Maksim ini memaksimalkan kesetujuan dan meminimalkan ketidaksetujuan di antara mereka. Dari jawaban tuturan Laras di atas, terlihat bahwa Laras tidak memaksimalkan kesetujuan atau kecocokan terhadap tuturan Vino. Tuturan Laras "Trus kalo gue nggak papa, perbuatan lu tadi bisa dimaafin” merupakan bentuk penolakan atau ketidaksetujuan terhadap tuturan Vino, tersebut telah melanggar prinsip kesantunan dari maksim kesetujuan. 


\section{Pelanggaran Maksim Kesimpatian}

Maksim kesimpatian mengharuskan semua peserta pertuturan untuk memaksimalkan rasa simpati dan meminimalkan rasa antipati kepada lawan tuturnya.

\section{Percakapan Dialog 43}

Dialog: Vino tidak suka kepada Laras, karena Laras kata-katanya suka memancing emosi.

Leon: "Udah..udah Vin"

Vino: "Gue nggak suka diginiin, lu lihat sendirikan jelas-jelas dia yang nyolot duluan."

(Sumber: Sinetron “Siapa Takut Jatuh Cinta,” episode 1, 13 November 2017)

Tuturan Vino pada kutipan di atas melanggar prinsip kesantunan, yaitu maksim kesimpatian. Maksim ini berhubungan dengan penilaian baik atau buruk penutur terhadap dirinya sendiri atau orang lain, dari jawaban Vino di atas terlihat bahwa Vino tidak memaksimalkan rasa simpati dan meminimalkan rasa antipati. Rasa simpati yang sangat minimal dan rasa antipati terlihat dengan penggunaan tuturan "gue nggak suka diginiin," dari tuturan tersebut telah melanggar maksim kesimpatian. Berdasarkan tuturan Vino tersebut, terlihat bahwa Vino tidak memaksimalkan rasa simpati dan meminimalkan rasa antipati kepada lawan tuturnya.

\section{Percakapan Dialog 44}

Dialog: OB menjawab pertanyaan Laras dengan emosi.

Laras: "Iya tau kok, cuma mahal banget makanan di sini"

OB: "Baru tau emangnya, di sini mall bukan kampus."

(Sumber: Sinetron “Siapa Takut Jatuh Cinta,” episode 1, 13 November 2017)

Tuturan OB pada kutipan di atas melanggar prinsip kesantunan, yaitu maksim kesimpatian. Maksim ini berhubungan dengan penilaian baik atau buruk penutur terhadap dirinya sendiri atau orang lain. Dari jawaban OB kepada Laras di atas, terlihat bahwa OB tidak memaksimalkan rasa simpati dan meminimalkan rasa antipati kepada Laras. Rasa simpati yang sangat minimal dan rasa antipati yang maksimal terhadap Laras terlihat dengan penggunaan kata "baru tau emangnya” yang digunakan OB untuk menunjukkan ketidaksukaan kepada Laras.

\section{Faktor Penyebab Ketidaksantunan}

Berdasarkan hasil penelitian yang diunduh dan kemudian ditranskripsikan ke dalam bentuk tulisan. Dari hasil 5 episode diunduh diperoleh tentang faktor yang menyebabkan terjadi 
pelanggaran prinsip kesantunan berbahasa dalam "Sinetron Siapa Takut Jatuh Cinta." Faktor tersebut adalah kritik secara langsung dengan kata-kata kasar, dorongan rasa emosi penutur, protektif terhadap pendapat, sengaja melawan lawan tutur, dan sengaja memojokkan mitra tutur.

\section{Kritik secara Langsung dengan Kata-kata Kasar}

Kritik kepada lawan tutur secara langsung dan dengan menggunakan kata-kata kasar akan menyebabkan sebuah pertuturan menjadi tidak santun atau jauh dari peringkat kesantunan.

\section{Tuturan 1}

Laras: "Hah..hah..itu mobil lu kan! Mobilnya doang yang bagus, tapi yang bawa oon banget, ngapain juga lu kebut-kebutan di jalan raya, bahayain orang lain."

(Sumber: Sinetron “Siapa Takut Jatuh Cinta,” episode 1, 13 November 2017)

Dalam tuturan di atas tidak santun, karena tuturannya bersifat langsung dan menggunakan kata-kata kasar. Tuturan di atas jelas menyinggung perasaan lawan tutur. Mungkin akan lebih santun kalau kata "oon banget” diganti dengan ungkapan "kurang hati-hati," maka ungkapan tersebut akan lebih santun.

\section{Tuturan 2}

Laras: "Haah haah hah hah gue pikir gue ketabrak, awas lu ya ..bisa-bisanya bawa mobil kayak gitu ..heh..heh..ini nih mobil yang mau nabrak gue, kurang ajar, nyebelin bener-bener nyebelin."

(Sumber: Sinetron "Siapa Takut Jatuh Cinta," episode 1, 13 November 2017)

Dalam tuturan di atas, tidak santun karena tuturannya bersifat langsung dan menggunakan kata-kata kasar. Tuturan di atas jelas menyinggung perasaan lawan tutur. Mungkin akan sedikit lebih santun kalau kata "kurang ajar" diganti dengan ungkapan “kurang hati-hati," maka ungkapan tersebut akan lebih santun.

\section{SIMPULAN}

Berdasarkan hasil analisis data yang dipaparkan sebelumnya, diperoleh beberapa simpulan tentang kesantunan dalam sinetron "Siapa Takut Jatuh Cinta” sebagai berikut.

1. Pelanggaran prinsip kesantunan berbahasa dalam sinetron "Siapa Takut Jatuh Cinta." Dalam pelanggaran prinsip kesantunan berbahasa terdapat 4 episode yang diteliti. Terdapat 6 maksim yaitu wujud pelanggaran maksim kebijaksanaan terdapat 16 pelanggaran kesantunan, maksim 
penerimaan terdapat 4 pelanggaran, maksim kemurahan terdapat 16 pelanggaran, maksim kerendahan hati terdapat 3 pelanggaran, maksim kecocokan terdapat 3 pelanggaran dan maksim kesimpatian terdapat 2 pelanggaran.

2. Faktor penyebab ketidaksantunan berbahasa dalam sinetron "Siapa Takut Jatuh Cinta." Dalam faktor penyebab ketidaksantunan terdapat 5 faktor yaitu kritik secara langsung dengan kata-kata kasar terdapat 5 penyebab ketidaksantunan. Dorongan secara emosi penutur terdapat 5 penyebab ketidaksantunan. Protektif terhadap pendapat, 6 penyebab ketidaksantunan. Sengaja menuduh lawan tutur terdapat 6 penyebab ketidaksantunan, dan sengaja memojokkan mitra tutur terdapat 7 penyebab ketidaksantunan.

\section{DAFTAR RUJUKAN}

Mahdian. 2015. Pelanggaran dan Pematuhan Prinsip Kerja Sama serta Implikaturnya dalam Novel Ronggeng Dukuh Paruk Karya Ahmad Tohari. Tesis tidak diterbitkan. Banjarmasin: Program Pascasarjana Pendidikan Bahasa dan Sastra Indonesia ULM Banjarmasin.

Musaba, Zulkifli. 2012. Terampil Berbicara. Yogyakarta: CV. Aswaja Pressindo.

Nisa, F. 2016. "Pelanggaran Prinsip Kesantunan dalam Wacana Tutur Basuki Tjahaja Purnama (Ahok). Jurnal Stilistika. No. 1, tahun 2016, Vol. 1. Banjarmasin: STKIP PGRI Banjarmasin.

Sauri, S. 2005. Pendidikan Berbahasa Santun. Bandung: PT Genesindo.

Setyawati, N. 2010. Analisis Kesalahan Berbahasa Indonesia. Surakarta: Yuma Pustaka.

Sibarani, R. 2004. Antropolinguistik. Medan: Poda. 